\title{
Magnitude of health problems among late adolescents: a cross sectional study
}

\author{
Vivek Baliram Waghachavare*, Manohar Shankarrao Chavan, Alka Dilip Gore, \\ Jitesh Hanmantrao Kadam, Vishwajeet Manohar Chavan, Girish Bhimrao Dhumale
}

Bharati Vidyapeeth Deemed University Medical College \& Hospital, Sangli, Maharashtra, India

Received: 02 April 2016

Accepted: 11 April 2016

*Correspondence:

Dr. Vivek Baliram Waghachavare,

E-mail: vivek416416@gmail.com

Copyright: () the author(s), publisher and licensee Medip Academy. This is an open-access article distributed under the terms of the Creative Commons Attribution Non-Commercial License, which permits unrestricted non-commercial use, distribution, and reproduction in any medium, provided the original work is properly cited.

\begin{abstract}
Background: Adolescence is a very important phase of growth and maturity, but is often related with mental and behavioural problems. However, very few attempts are made to understand the magnitude of adolescent health problems; hence the current study was planned.

Methods: It is a cross-sectional study conducted among arts, commerce and science college students from Sangli, (Maharashtra) India; by using cluster random sampling. Due ethical considerations and written consent were undertaken. The study tool was self-administered questionnaire with inventories like SPIN, DASS-21 and PSST-A. Analysis was done using percentages and chi-square test. Microsoft Excel 2007 and SPSS-22 were used for analysis.

Results: Eight hundred one $(67.5 \%)$ students had psychological problems with anxiety being the commonest. Menstrual problems were reported by 413 (58.4\%) female students. Psychological problems were associated with menstrual problems.

Conclusions: Majority of students had some psychological problem. Menstrual problems were present in more than $50 \%$ female students. There is unmet need for proper guidance and help regarding health.
\end{abstract}

Keywords: Adolescence, Mental health, Adolescent behaviours, Menstruation disorders, Reproductive health

\section{INTRODUCTION}

The adolescence means "growing to maturity" in Latin. WHO defines this phase from 10 to 19 years of age. During adolescence, rapid development of the body interacts with social development resulting in many transitions in an individual; required to function as a productive adult. ${ }^{2}$ The adolescents are resource to the society with their zeal and energy; however they are vulnerable due to biological and environmental pressures. Puberty results into physical maturation with increased fitness as well as emotional, cognitive and behavioral changes. But these changes all bring the increased mortality \& morbidity from injuries, suicide, mental disorders, substance abuse and eating disorders. ${ }^{3}$ Adolescence and young adulthood coincide with major changes in health problems and determinants of health in later life. ${ }^{4}$

In developed countries like USA, substantial efforts are taken for development of adolescent health; however, Indian scenario is lagging due to limited availability of specialized training. The adolescent health is hampered due to deficient specialized medical care and absence of proper policies. These problems are further escaladed due to lack of health seeking behaviour in adolescents. The unmet needs for mental health services are almost $100 \%$ in many developing countries. 5

Young people are commonly regarded as healthy and hence few attempts have been made to systematically measure their health. ${ }^{4}$ There is a serious shortage of 
literature on adolescents; resulting in a barrier to understand their needs and to identifying appropriate programmes to improve their lives. Hence, the current study was undertaken to find out the magnitude of reproductive health, mental health and behavioral problems in late adolescents.

\section{METHODS}

It is a cross-sectional study, conducted from June 2012 to June 2013. Study population was the students from arts, commerce and science degree (graduation) colleges from Sangli District, Maharashtra, India. Cluster random sampling was used to collect the data. The calculated minimum sample size was 1000 . The study proposal was approved by Institutional Ethical Committee and permission was acquired from the respective head of the selected institutes. Written consent was acquired from every participant.

The study tool was self-administered, pre-tested questionnaire based on published literature; developed with the help of specialists and experienced faculty. Social Phobia Inventory (SPIN) ${ }^{6}$, DASS-21(Depression, Anxiety and Stress Scale, a short version) ${ }^{7}$ and Premenstrual syndrome screening tool modified for adolescent (PSST-A) ${ }^{8}$ were used to identify various psychological problems. The study tool also had questions regarding substance abuse (viz. smoking, alcohol, ganja, tobacco chewing, glue sniffing etc.), symptoms of reproductive tract infections (i.e. genital blisters, swelling over groin, discolouration of urine, genital discharge, difficulty in micturition, itching over genital region, genital sores etc. $)^{9}$, self-perceived body weight and body image anxiety. ${ }^{10}$ Appropriate pilot studies were conducted for finalizing study tool and study procedure. The data from the pilot studies was not used in the final analysis.

Analysis was done using percentages and chi-square test. Microsoft Excel-2007 and SPSS-22 were used for analysis.

\section{RESULTS}

Total 1186 participants had completed the questionnaire in the requisite manner and hence included in the final analysis. Considering the socio-demographic profile of the study participants nearly $60 \%$ were females. Majority of the study participants were 18 years old. Maximum study participants i.e, $57.34 \%$ belonged to commerce stream of education followed by science and arts respectively.

More than two third of the students were from urban area. Almost $90 \%$ of them stayed at their homes; while only $5 \%$ students stayed in hostels. Over $70 \%$ of the students belonged to nuclear family. More than one third of participants belonged to socioeconomic class-I, while only $10 \%$ belonged to class-V. (Table 1 )
Among the students; $862(72.7 \%)$ supported addition of reproductive health education, 1114 (93.9\%) supported addition of mental health and de-addiction related education in their curriculum. Need for health cell in college was felt by $1146(96.6 \%)$ students. Only 3.4\% students were comfortable about discussing health problems with teachers, while $56.7 \%$ and $56.3 \%$ with mother and friends respectively.

Table 1: Distribution of socio-demographic variables of the study participants.

\begin{tabular}{|c|c|c|c|}
\hline \multicolumn{2}{|c|}{ Socio-demographic Variables } & \multirow{2}{*}{$\begin{array}{l}\text { N (1186) } \\
848\end{array}$} & \multirow{2}{*}{$\begin{array}{l}\text { Percen } \\
71.5\end{array}$} \\
\hline & 18 years & & \\
\hline Age & 19 years & 338 & 28.5 \\
\hline \multirow{2}{*}{ Gender } & Female & 707 & $59.61 \%$ \\
\hline & Male & 479 & $40.39 \%$ \\
\hline \multirow{3}{*}{$\begin{array}{l}\text { Stream of } \\
\text { education }\end{array}$} & Arts & 215 & 18.1 \\
\hline & Commerce & 680 & 57.3 \\
\hline & Science & 291 & 24.5 \\
\hline \multirow{2}{*}{$\begin{array}{l}\text { Permanent } \\
\text { Residence }\end{array}$} & Rural & 399 & 33.6 \\
\hline & Urban & 787 & 66.4 \\
\hline \multirow[b]{3}{*}{$\begin{array}{l}\text { Current } \\
\text { Residence }\end{array}$} & Home & 1054 & 88.9 \\
\hline & Hostel & 60 & 5.1 \\
\hline & $\begin{array}{l}\text { Other (With } \\
\text { relatives, } \\
\text { shared flats } \\
\text { etc.) }\end{array}$ & 72 & 6.1 \\
\hline \multirow{5}{*}{$\begin{array}{l}\text { Prasad's } \\
\text { Socioeconomic } \\
\text { classification }\end{array}$} & I & 424 & 35.8 \\
\hline & II & 295 & 24.9 \\
\hline & III & 165 & 13.9 \\
\hline & IV & 182 & 15.3 \\
\hline & $\mathrm{V}$ & 120 & 10.1 \\
\hline \multirow{2}{*}{ Family Type } & Nuclear & 841 & 70.9 \\
\hline & Joint & 345 & 29.1 \\
\hline
\end{tabular}

Eight hundred one $(67.5 \%)$ students had at least one of the psychological problem, while 476 (40.1\%) had multiple psychological problems. There was no association of gender, permanent residence (urban - rural) or socioeconomic status with presence of psychological problems. Stress, anxiety, depression and social phobia were present in $324(27.3 \%), 459(38.7 \%), 378(31.9 \%)$ and $317(27 \%)$ students respectively. Total $643(54.2 \%)$ students had at least stress, anxiety or depression and 153 $(12.9 \%)$ had all the three. One hundred ninety two (16.2\%) students perceived that their body type was abnormal i.e. they are either overweight $77(6.5 \%)$ or underweight $115(9.7 \%)$. Body image anxiety was present in $159(13.4 \%)$ students.

Any addiction was reported by $22(1.9 \%)$ students. Thirty-one $(2.61 \%)$ students were sexually active, among them $12(38.7 \%)$ had unprotected sexual intercourse. Heterosexual attraction was reported by 291 (24.54\%) students and homosexual by $38(3.2 \%)$ students. One hundred thirteen $(9.53 \%)$ fantasized about sex and 112 
(9.44\%) watched porn. The routine life of $123(10.4 \%)$ students was hampered sexual thoughts or exposure. Male predominance was observed in all the sexual thoughts and behaviour. Symptoms of reproductive tract infection were reported by $96(8.1 \%)$ students.

Mean age of menarche was 14.5 years; there was no significant difference in age of menarche of girls from rural and urban area. Menstrual problems were reported by $413(58.4 \%)$ female students. Dysmenorrhea 332 (47\%), was the commonest. For the menstrual problems, $250(35.4 \%)$ students had consulted the doctor (Figure 1).

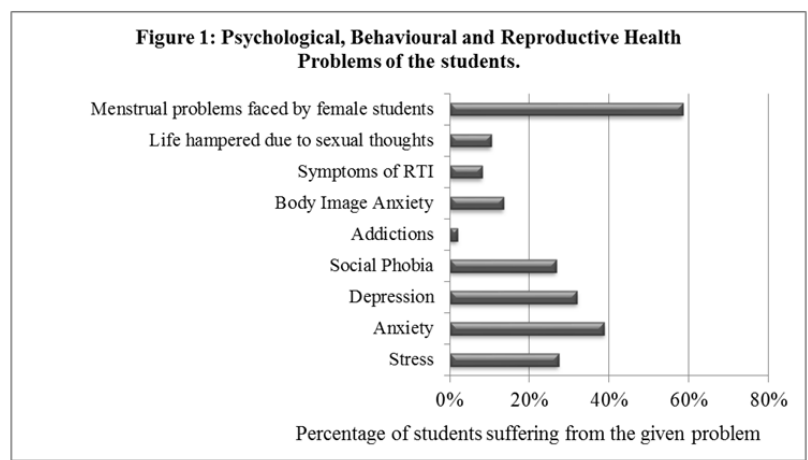

Figure 1: Psychological, behavioural and reproductive health problems of the students.

Higher age was associated with stress (Chi-square $=10.7$, $\mathrm{p}=0.001)$ and anxiety (Chi-square $=7.8, \mathrm{p}=0.005)$
Anxiety was associated with gender (Chi-square $=4.5$, $\mathrm{p}=0.035)$, with female preponderance. Education stream was associated with stress (Chi-square $=10.4, \mathrm{p}=0.005$ ), anxiety (Chi-square $=26.4, \mathrm{p}=0.000$ ), depression (Chisquare $=18.7, \mathrm{p}=0.000)$, social phobia (Chi-square $=13.5$, $\mathrm{p}=0.001$ ) and body image anxiety (Chi-Square $=9.263, \mathrm{p}$ $=0.01$ ); these were highest in arts students, followed by commerce and science. Depression was common in students from rural area (Chi-square=4.6, $\mathrm{p}=0.03$ ). Anxiety was associated current residence (Chisquare=8.19, $\mathrm{p}=0.017$ ), students living in home were prone as compared to hostel dwellers.

Social phobia was present in 203 (29\%) female and 114 (24\%) male students. There was statistically significant association of social phobia with socio-economic status (Chi-square $=13.832, \mathrm{df}=4$, $\mathrm{p}$-value $=0.008$ ), with general trend of increase in social phobia from class-I to class-V.

Gender was associated with body type perception (Chisquare $=14.2, \mathrm{p}=0.008$ ) and body image anxiety (Chisquare $=5.7, \mathrm{p}=0.017$ ). Higher percentage of girls perceived themselves overweight and boys perceived themselves underweight. Body image anxiety was present in $11 \%$ girls as compared to $16 \%$ boys.

For the symptoms of reproductive tract infection (RTI), only $46(47.9 \%)$ students had consulted the doctor. The association of symptoms of RTI and gender was statistically significant (Chi-Square value $=10.9$, $\mathrm{p}=0.001$ ), with male preponderance.

Table 2: Association between psychological, behavioural and reproductive health problems with socio-demographic factors.

\begin{tabular}{|c|c|c|c|c|c|c|}
\hline \multirow{2}{*}{$\begin{array}{l}\text { Psychological, behavioural and } \\
\text { reproductive health problems }\end{array}$} & \multicolumn{6}{|c|}{ Important socio-demographic factors } \\
\hline & Age & Gender & $\begin{array}{l}\text { Educational } \\
\text { stream }\end{array}$ & SES & $\begin{array}{l}\text { Permanent } \\
\text { residence }\end{array}$ & $\begin{array}{l}\text { Current } \\
\text { residence }\end{array}$ \\
\hline Stress & $\sqrt{ }$ & & $\sqrt{ }$ & & & \\
\hline Anxiety & $\sqrt{ }$ & $\sqrt{ }$ & $\sqrt{ }$ & & & $\sqrt{ }$ \\
\hline Depression & & & $\sqrt{ }$ & & $\sqrt{ }$ & \\
\hline Social phobia & & & $\sqrt{ }$ & $\sqrt{ }$ & & \\
\hline Body image anxiety & & $\sqrt{ }$ & $\sqrt{ }$ & & & \\
\hline Symptoms of RTI & $\sqrt{ }$ & $\sqrt{ }$ & $\sqrt{ }$ & & & \\
\hline Life hampered by sexual thoughts & & $\sqrt{ }$ & & & & \\
\hline Menstrual problems & & & $\sqrt{ }$ & $\sqrt{ }$ & $\sqrt{ }$ & \\
\hline
\end{tabular}

The day-to-day activity or working capability of males was significantly more hampered due to sexual behaviour or thoughts (Chi-square $=80.8, \mathrm{p}=0.000)$ as compared to females.

Menstrual problems were associated with socioeconomic status (Chi-square $=9.9, \mathrm{p}=0.042)$; with trend of decrease in menstrual problems from class - I to V. These problems were associated with Arts stream of education (Chi-square $=22.3, \mathrm{p}=0.000)$. They were significantly more in urban students $($ Chi-square $=6.4$, $\mathrm{p}$ value $=0.01)$.

Symptoms of reproductive tract infection were more common among the girls suffering with menstrual 
problems; the association was statistically significant (chi square $=9.3, \mathrm{p}=0.002)($ Table 2$)$.

Social phobia was associated with stress (chi-square $=9.9$, $\mathrm{p}=0.002$ ), anxiety (chi-square $=23.9, \quad \mathrm{p}=0.000$ ) and depression (chi-square $=11.4, \mathrm{p}=0.001$ ). Similarly, body type perception was associated with stress (chisquare $=12.5, p=0.002)$, anxiety (chi-square $=6.6, p=0.04)$ and depression (chi-square $=10.1, \mathrm{p}=0.006$ ). Stress, depression and anxiety were higher among perceived underweight, followed by perceived overweight and then perceived normal. Stress (chi-square=7.8, p=0.005), depression (chi-square $=7.9, \mathrm{p}=0.005$ ) and anxiety (chisquare $=5.6, \mathrm{p}=0.018$ ), were higher among those having body image anxiety.

Presence of symptoms of reproductive tract infection was associated with stress (Chi-square $=9.3, \mathrm{p}=0.002)$, anxiety (Chi-square=6.7, $\mathrm{p}=0.01)$ and depression (Chisquare=5.6, $\mathrm{p}=0.02$ ). Students disturbed due to their sexual behaviour or thoughts had significantly higher stress (Chi-square $=12.3, \quad \mathrm{p}=0.000)$, anxiety (Chisquare $=9.1, \mathrm{p}=0.003$ ) and depression (Chi-square $=9.2$, $\mathrm{p}=0.002)$.

Table 3: Association between psychological, behavioural and reproductive health problems.

\begin{tabular}{|c|c|c|c|c|c|c|c|c|}
\hline Problems & Stress & Anxiety & Depression & $\begin{array}{l}\text { Social } \\
\text { phobia }\end{array}$ & BIA & RTI & ST & $\begin{array}{l}\text { Menstrual } \\
\text { problems }\end{array}$ \\
\hline Stress & & & & $\sqrt{ }$ & $\sqrt{ }$ & $\sqrt{ }$ & $\sqrt{ }$ & $\sqrt{ }$ \\
\hline Anxiety & & & & $\sqrt{ }$ & $\sqrt{ }$ & $\sqrt{ }$ & $\sqrt{ }$ & $\sqrt{ }$ \\
\hline Depression & & & & $\sqrt{ }$ & $\sqrt{ }$ & $\sqrt{ }$ & $\sqrt{ }$ & \\
\hline Soc. Phobia & $\sqrt{ }$ & $\sqrt{ }$ & $\sqrt{ }$ & & $\sqrt{ }$ & $\sqrt{ }$ & $\sqrt{ }$ & \\
\hline BIA & $\sqrt{ }$ & $\sqrt{ }$ & $\sqrt{ }$ & $\sqrt{ }$ & & & & \\
\hline RTI & $\sqrt{ }$ & $\sqrt{ }$ & $\sqrt{ }$ & $\sqrt{ }$ & & & & $\sqrt{ }$ \\
\hline ST & $\sqrt{ }$ & $\sqrt{ }$ & $\sqrt{ }$ & $\sqrt{ }$ & & & & \\
\hline $\begin{array}{l}\text { Menstrual } \\
\text { Problems }\end{array}$ & $\sqrt{ }$ & $\sqrt{ }$ & & & & $\sqrt{ }$ & & \\
\hline
\end{tabular}

The association of social phobia with body type perception (Chi-square $=16.6, \mathrm{p}=0.000)$ was statistically significant; $43 \%$ perceived underweight and $27 \%$ perceived overweight had social phobia as compared to only $25 \%$ perceived normal. Significant association was observed between body image anxiety and social phobia $($ Chi-Square $=8.9, \mathrm{p}=0.003)$.

Social Phobia was higher among students with symptoms of reproductive tract infection (Chi-Square $=8.8135$, $\mathrm{p}=0.0029$ ). Higher percentage of students with day-to-day life hampered due to sexual behaviour or sexual thoughts had social phobia (Chi-Square $=4.7, \mathrm{p}=0.029$ ).

Seventy (91\%) perceived overweight and 89(77\%) perceived underweight students had body image anxiety, the association was significant (Chi-square=5.9, $\mathrm{p}=0.015)$.

The association of menstrual problems with stress (chisquare $=21.5, \mathrm{p}=0.000)$ and anxiety (chi-square $=4.07, \mathrm{p}=$ 0.01 ) was significant (Table 3 ).

\section{DISCUSSION}

Al-Gelban (2007) had observed that $59.4 \%$ Saudi Arabian adolescents had stress, anxiety or depression and $22.6 \%$ had co-morbidity of all the three. ${ }^{11} \mathrm{We}$ observed that $54.2 \%$ students had stress, anxiety or depression and comorbidity in $12.9 \%$; lower as compared to Al-Gelban's observations. Observed variation may be attributed to cultural, social and economic differences.

Bayram and Bilgel (2008) observed that depression was present in $27 \%$ of the Turkish University students. ${ }^{12} \mathrm{We}$ observed depression in $31.9 \%$ adolescents, higher than the mentioned studies. Burden of depression is considered to be greater in lower income countries due to lack of awareness and help might be the reason. ${ }^{13}$ This may explain the observed difference.

Mohanraj et al. in Chennai observed depression among $60.8 \%$ students. ${ }^{14}$ The variation observed in results in current study and other Indian studies can be attributed to personal \& genetic vulnerability, geographical difference, socio-economic differences and to difference in inventories. $^{15}$

We observed social phobia in $27 \%$ students with female preponderance. Al-Hinai et al., observed that, depending on the assessment instrument, $37 \%$ to $54 \%$ Omani college students meet criteria for Social Anxiety Disorder. ${ }^{16}$ The difference in the results can be attributed to cross cultural variation, as observed by Hofmann et al. ${ }^{17}$ 
We observed that social phobia increased from class -I to class- $\mathrm{V}$, indicating that financial scarcity may lead to social phobia. Similar observations were made by Schneiner et al (1990). ${ }^{18}$ Similar to our results, Mehtalia (2004) had observed association of depression and social phobia in adolescents from Ahmadabad. ${ }^{19}$

Al Sabbah et al had observed body image anxiety in $32.1 \%$ Palestinian adolescents. ${ }^{20}$ Dixit et al. observed Body image dissatisfaction in $26.6 \%$ adolescent girls in Lucknow. ${ }^{21}$ In the current study body image anxiety was present in $13.4 \%$ adolescents. Petroski et al had observed higher prevalence of body image anxiety in urban residents as compared to their rural counterparts. ${ }^{22}$ This phenomenon could have played role, in our result.

Stice et al, concluded body image anxiety as risk factor of depression. ${ }^{23} \mathrm{We}$ found significant association between body image anxiety and depression. In accordance with Mirza et al ${ }^{24}$ we observed that body image anxiety was common among perceived overweight. Izgic et $\mathrm{al}^{25}$ observed that body image anxiety was associated with social phobia. Similar result was appreciated in the current study.

Slap observed that problems associated with menstruation affect $75 \%$ of adolescents. ${ }^{26}$ Thakre et al. observed menstrual problems among $71.8 \%$ adolescent girls. ${ }^{27}$ However we observed menstrual problems in $58.4 \%$ girls. The difference is attributed to different attitude and geographical variations.

Singh A et al observed that $73.83 \%$ subjects complained dysmenorrhea. ${ }^{28}$ In the current study was reported by only $42.5 \%$ subjects, lower than above mentioned studies. However the results are closer to observed result of $50.6 \%$ dymenorrhoea among girls from Bhavnagar, by Verma et $\mathrm{al}^{29}$ The dysmenorrhea and its severity are perceptive and depends on personal threshold for pain. This may be the reason for observed differences in the results.

In the Zurich cohort study by Merikangas et al strong association between menstrual syndrome and anxiety was observed. ${ }^{30}$ In the current study, there was association of stress and anxiety with menstrual problems.

The study is based on self-addressed questionnaires, hence reporting bias cannot be completely eliminated. The tools used to identify the problems are for screening purpose and for community and social interventions. But the results are not useful for initiation of therapeutic interventions.

Although problems statement can be defined for the group as whole, but individuals with problem cannot be traced for further examination due to confidentiality reasons. The study is conducted in colleges; hence results cannot be applied to all the adolescents in the community.
Differences in psychological problems like stress, anxiety and depression in pre-examination, examination and post examination period are not considered.

Limitations of the study is based on self-addressed questionnaires, hence reporting bias cannot be completely eliminated. The tools used to identify the problems are for screening purpose and for community and social interventions. But the results are not useful for initiation of therapeutic interventions.

Although problems statement can be defined for the group as whole, but individuals with problem cannot be traced for further examination due to confidentiality reasons. The study is conducted in colleges; hence results cannot be applied to all the adolescents in the community.

Differences in psychological problems like stress, anxiety and depression in pre-examination, examination and post examination period are not considered

\section{CONCLUSION}

Majority of students had some psychological problem, especially arts students. Behavioural problems like addictions were present in less than $2 \%$ students with male preponderance. Symptoms of reproductive tract infection were observed by nearly $8 \%$ respondents, with very poor health seeking behaviour. Menstrual problems were present in more than half female students. Girls from urban area and higher socioeconomic class were more prone. Only $35.4 \%$ girls had ever sought advice from doctors for menstrual problems. Reproductive health problems were present in $40 \%$ students and were associated with psychological problems. The sexually active students were more likely to have symptoms of reproductive tract infection with few getting medical consultation.

Arts stream was associated with most psychological problems, many due to lack of scientific knowledge and stress about future.

Majority of students favoured inclusion of education related to reproductive health, mental health and deaddiction, in the curriculum. Similarly more than $96 \%$ supported an idea of health cell in the college. Psychological, behavioural and reproductive health problems are faced by many students. There is unmet need for proper guidance and help regarding health.

It is recommended to introduce health cell with specialist in every college. Inclusion of reproductive health, stress management and de-addiction topics in the curriculum. Knowledge regarding safe sexual practices, contraception and menstrual problems must be included in the teaching programme. Experts should conduct routine physical examination and screening of all the students in the college. Active efforts to bridge the communication gap between teachers and students. 
Funding: No funding sources

Conflict of interest: None declared

Ethical approval: The study was approved by the Institutional Ethics Committee

\section{REFERENCES}

1. World Health Organization. The second decade: improving adolescent health and development. Geneva: World Health Organization, 2001.

2. Viner RM, Ozer EM, Denny S, Marmot M, Resnick $\mathrm{M}$, Fatusi A et al. Adolescence and the social determinants of health. Lancet. 2012;379:1641-52.

3. Patton GC, Viner RM. Pubertal transitions in health. Lancet 2007;369:1130-9.

4. Patton GC, Coffey C, Cappa C, Currie D, Riley LM, Gore FM et al. Health of the world's adolescents: a synthesis of internationally comparable data. Lancet. 2012;379:1665-75.

5. Tonin V. Young people seeking mental-health care. Lancet. 2007;369:1239-40.

6. Connor KM, Davidson JR, Churchill LE, Sherwood A, Foa E, Weisler RH. Psychometric properties of the Social Phobia Inventory (SPIN). New self-rating scale. Br J Psychiatry. 2000;176:379-86.

7. Lovibond SH, Lovibond PF. Manual for the Depression Anxiety Stress Scales. 2nd ed. Sydney: Psychology Foundation; 1995.

8. Steiner M, Peer M, Palova E, Freeman EW, Macdougall M, Soares CN. The premenstrual symptoms screening tool revised for adolescents (PSST-A): prevalence of severe PMS and premenstrual dysphoric disorder in adolescents. Arch Womens Ment Health. 2011;14(1):77-81.

9. World Health Organization. Guidelines for the management of sexually transmitted infections. Geneva: World Health Organization, 2001.

10. American Psychiatric Association. Diagnostic and statistical manual of mental disorders. 4th edn. Text rev. Washington DC: Am J Psychiatry. 2000.

11. Al-Gelban KS. Depression, anxiety and stress among Saudi adolescent school boys. J R Soc Promot Health. 2007;127(1):33-7.

12. Bayram N, Bilgel N. The prevalence and sociodemographic correlations of depression, anxiety and stress among a group of university students. Soc Psychiatry Psychiatr Epidemiol. 2008;43(8):667-72.

13. The world health report 2001- mental health: new understanding, new hope. Geneva. Bull World Health Organ. 2001;79(11):1085.

14. Mohanraj R, Subbaiah K. Prevalence of depressive symptoms among urban adolescents in South India. J Indian Assoc Child Adolesc Ment Health 2010;6:33-43.

15. Thapar A, Collishaw S, Pine DS, Thapar AK. Depression in adolescence. Lancet. 2012;379:105667.

16. Al-Hinai SS, Al-Saidy O, Dorvlo ASS. Culture and prevalence of social phobia in a college population in Oman. In: Landow M, eds. College students: mental health and coping strategies. Hauppauge, NY: Nova Science Publishers; 2006:115-32.

17. Hofmann SG, Asnaani A, Hinton DE. Cultural aspects in social anxiety and social anxiety disorder. Depress Anxiety. 2010;27:1117-27.

18. Schneier FR, Johnson J, Hornig CD, Liebowitz MR, Weissman MM. Social phobia: comorbidity and morbidity in an epidemiologic sample. Arch Gen Psychiatry.1992;49(4):282-8.

19. Mehtalia K, Vankar GK. Social anxiety in adolescents. Indian J Psychiatry. 2004;46:221-7.

20. Al Sabbah H, Vereecken C, Abdeen Z, Coats E, Maes L. Associations of overweight and of weight dissatisfaction among Palestinian adolescents: findings from the national study of Palestinian schoolchildren (HBSC-WBG2004). J Hum Nutr Diet. 2009;22(1):40-9.

21. Dixit S, Agarwal GG, Singh JV, Kant S, Singh N. A study on consciousness of adolescent girls about their body image. Indian $\mathrm{J}$ Comm Med. 2011;36:197-202.

22. Petroski EL, Pelegrini A, Glaner MF. Reasons and prevalence of body image dissatisfaction in adolescents. Ciênc Saúde coletiva. 2012;17(4).

23. Stice E, Hayward C, Cameron RP, Killen JD, Taylor CB. Body-image and eating disturbances predict onset of depression among female adolescents: a longitudinal study. J Abnorm Psychol. 2000;109(3):438-44.

24. Mirza NM, Davis D, Yanovski JA. Body dissatisfaction, self-esteem, and overweight among inner-city Hispanic children and adolescents. J Adolesc Health. 2005;36(3):267.e16-267e20.

25. Izgic F, Akyuz G, Dogan O, Kugu N. Social phobia among university students and its relation to selfesteem and body image. Can J Psychiatry. 2004;49:630-6.

26. Slap GB. Menstrual disorders in adolescence. Best Pract Res Clin Obstet Gynaecol. 2003;17:75-92.

27. Thakre SB, Thakre SS, Ughade SU, Thakre AD. Urban-rural differences in menstrual problems and practices of girl students in nagpur, India. Indian Pediatr. 2012;49:733-6.

28. Singh A, Kiran D, Singh H, Nel B, Singh P, Tiwari P. Prevalence and severity of dysmenorrhea: a problem related to menstruation, among first and second year female medical students. Indian J Physiol Pharmacol. 2008;52:389-97.

29. Verma PB, Pandya CM, Ramanuj VA, Singh MP. Menstrual pattern of adolescent school girls of bhavnagar(Gujarat). NJIRM. 2011;2:38-40.

30. Merikangas KR, Foeldenyi M, Angst J. The Zurich Study. XIX. Patterns of menstrual disturbances in the community: results of the Zurich Cohort Study. Eur Arch Psychiatry Clin Neurosci. 1993;243:2332.

Cite this article as: Waghachavare VB, Chavan MS, Gore AD, Kadam JH, Chavan VM, Dhumale GB. Magnitude of health problems among late adolescents : a cross sectional study. Int J Community Med Public Health 2016;3:1027-32. 